\title{
ASSOCIATION OF INTERLEUKIN 6 PROMOTER POLYMORPHISM (-174G/C) WITH IL-6 LEVEL AND OUTCOME IN SEVERE SEPSIS
}

\author{
Oḷegs Sabeḷnikovs*, Liene N̦ikitina-Zaḳe**, and Indulis Vanags* \\ * Rīga Stradiṇš University, Department of Anaesthesiology and Reanimatology, Dzirciema iela 16, Rīga, LV-1007, LATVIA \\ ** Latvian Biomedical Research and Study Centre, Rātsupītes iela 1, Rīga, LV-1067, LATVIA
}

Communicated by Rafails Rozentāls

\begin{abstract}
Interleukin (IL-6) is a key cytokine in the pathogenesis of severe sepsis. The importance of a regulatory polymorphism within the IL-6 promoter remains unclear in these patients. The aim of the study was to determine if IL-6 (-174 G/C) promoter polymorphism has an effect on IL-6 plasma level and outcome of severe sepsis. The study was conducted in general ICU of Stradinš Clinical University Hospital. A total of 103 critically ill patients with confirmed severe sepsis were prospectively included. Association analysis of the IL-6 (-174C) allele with serum level and clinical outcome was performed. We found no differences in genotype distribution between survivors and nonsurvivors. The serum IL-6 level was significantly higher in nonsurvivors compared with survivors. We found an association of genotype with the IL-6 level in nonsurvivors, but not in survivors. Our findings show a functional significance of IL-6 promoter polymorphisms in nonsurviving severe sepsis patients.
\end{abstract}

Key words: severe sepsis, interleukine-6, $-174 \mathrm{C} / \mathrm{G}$ polymorphism.

\section{INTRODUCTION}

Systemic inflammatory response to infection complicated with consecutive multiple organ failure is a major sign of severe sepsis (Levy, 2003). Severe sepsis is the leading cause of ICU (Intensive Care Unit) mortality worldwide (Angus, 2001).

IL-6 has been found to be a key cytokine in the pathogenesis of severe sepsis. The main biological effects of IL-6 are stimulation of B- and T-lymphocytes and induction of fever and acute phase response (Borden and Chin, 1994). Several studies have demonstrated a correlation of IL-6 serum concentration with severity and outcome in septic patients (Schlüter et al., 1991, Casey, 1993).

Genetic variation within the promoter region of IL-6 gene may affect the severity and outcome of sepsis. Recently, several variations of the IL-6 gene promoter region were described (Fishman et al., 1998). A polymorphism at -174 position of IL-6 promoter region with a $\mathrm{G}$ to $\mathrm{C}$ substitution $(-174 \mathrm{G} / \mathrm{C})$ shows functional significance in some inflammatory diseases and other clinical conditions (Flex, 2002; Balding, 2004).

In severe sepsis patients the functional significance of -174 remains unclear. In studies with healthy individuals contradicting results were observed. Benermo et al. reported significantly higher plasma IL-6 values in individuals with G genotype after vaccination with $1 \mathrm{~mL}$ of Salmonella typhii vaccine (Bennermo et al., 2004). Endler et al. found no differences in serum IL-6 level after LPS infusion in individuals with $\mathrm{C}$ and $\mathrm{G}$ genotype (Endler, 2004).

According to IL-6 (-174C) association with susceptibility and clinical outcome Shlüter et al. found no difference in genotype distribution between septic patients and healthy controls (Schlüter et al., 2002). In nonsurvivors significantly less GG homozygotes were observed compared with survivors and median systemic IL-6 levels in septic patients were closely correlated with outcome but were not associated with the IL-6 promoter genotype.

A bialelic polymorphism at promoter -174 position may be associated with a certain (low or high) IL- 6 producer phenotype and determinate interindividual variation in IL-6 mediated pathology.

We tested the hypothesis that the alternative allele (-174C) is associated with IL-6 systemic level and clinical outcome in patients with severe sepsis.

\section{MATERIAL AND METHODS}

The study was conducted in the tertiary mixed medicalsurgical adult ICU of Pauls Stradiňš Clinical University Hospital in Rīga in 2007. Patient data were screened daily and patients were included in the study cohort $(n=103)$ if they met proposed severe sepsis criteria (Levy et al., 2003) 
and were successfully genotyped at $-174 \mathrm{C} / \mathrm{G}$ SNP of IL-6 gene. Patients were included in this cohort on the calendar day that severe sepsis criteria were met. Ethical approval was obtained and all subjects consented to participate in the study.

The plasma of these patients was tested for IL-6 concentration by immunoassay (Biosorce Europe S.A. IL-6, EASIA) at the day of inclusion in this study.

The IL-6 promoter polymorphism -174 G/C was analysed as follows. Genomic DNA was extracted from peripheral blood sample using standard phenol-chloroform extraction method. The IL-6 promoter region harbouring the polymorphism of our interest was PCR amplified. For PCR amplification we used template DNA, forward primer 5'-TCGTGCATGACTTCAGCTTT-3', reverse primer 5'-GCCTCAGACATCTCCAGTCC-3' and PCR MasterMix (2 x) (Fermentas Life Sciences). The cycling conditions of PCR were as follows: 5 minutes of initial denaturation at $95{ }^{\circ} \mathrm{C}$, following 32 cycles of 15 seconds at 95 ${ }^{\circ} \mathrm{C}, 30$ seconds at $56{ }^{\circ} \mathrm{C}, 30$ seconds at $72{ }^{\circ} \mathrm{C}$, and final extension-10 minutes at $72{ }^{\circ} \mathrm{C}$. PCR products were then purified. We used the primer sequence

5'-TCATGGGAAAATCCCACATT-3' for sequencing reaction. Products were analysed by direct sequencing using a 3100 ABI prism DNA sequencer according to recommendations from the manufacturer.

Patients were followed up throughout their stay in the ICU to the clinical outcome.

Descriptive statistics were used for basic characterisation of the patient groups according to genotypes. Nonparametric statistics were applied. All statistical comparisons between groups were done with the Kruskal-Wallis test and the Mann-Whitney $U$-test. All statistical calculations were performed with commercially available statistical software („SPSS 15.0 for Windows”; SPSS Inc.). A value of $P<$ 0.05 was considered to indicate a statistical significance.

\section{RESULTS}

The demographic and clinical data at the day of inclusion of 103 Caucasian patients enrolled in this study are summarised in Table 1. The main reasons of severe sepsis were respiratory tract $(82 \%)$ and abdominal $(15 \%)$ infections. The overall survival was $59(57.3 \%)$ of 103 patients enrolled. Demographic data of the study population did not differ significantly between survivor and nonsurvivor groups.

We evaluated the association of IL-6 promoter polymorphism $(-174 \mathrm{G} / \mathrm{C})$ with outcome of severe sepsis. There was no significantly different distribution of genotypes between surviving and nonsurviving severe sepsis patients (Table 2). Comparing IL-6 median levels in surviving and nonsurviving severe sepsis patients, IL-6 plasma concentration was significantly increased in nonsurvivors. In survivors the median IL- 6 level was $190 \mathrm{pg} / \mathrm{mL}\left(5^{\text {th }} / 95^{\text {th }}\right.$ percen-
CHARACTERISTICS OF THE PATIENTS ${ }^{1}$

\begin{tabular}{lcc}
\hline & Survivors $(\mathrm{n}=59)$ & Nonsurvivors $(\mathrm{n}=44)$ \\
\hline Male patients (\% of total) & $45(58)$ & $32(42)$ \\
Age (years) & $64 \pm 5,4$ & $72 \pm 8,2$ \\
SOFA & $6 \pm 4$ & $9 \pm 4$ \\
ICU stay (days) & $4 \pm 3$ & $12 \pm 8$ \\
MPV days & $3 \pm 2$ & $11 \pm 5$
\end{tabular}

1 All values except gender are the mean $( \pm \mathrm{SD})$

Table 2

INTERLEUKINE-6 PROMOTER POLYMORPHISM (-174G/C) AND OUTCOME OF SEVERE SEPSIS

\begin{tabular}{lcc|c}
\hline & $\mathrm{C} / \mathrm{C}$ & $\mathrm{C} / \mathrm{G}$ & $\mathrm{G} / \mathrm{G}$ \\
\hline Survivors & $7(12 \%)$ & $32(54 \%)$ & $20(34 \%)$ \\
Nonsurvivors & $13(30 \%)$ & $21(48 \%)$ & $10(23 \%)$
\end{tabular}

$\overline{P>0.05, \text { Chi-square } 5.36}$

Table 3

INTERLEUKINE-6 PROMOTER POLYMORPHISM (-174G/C) AND IL-6 MEDIAN CONCENTRATION IN SURVIVORS AND NONSURVIVORS ${ }^{1}$

\begin{tabular}{lcccc}
\hline & $\mathrm{C} / \mathrm{C}(\mathrm{n}=13)$ & $\mathrm{C} / \mathrm{G}(\mathrm{n}=11)$ & $\mathrm{G} / \mathrm{G}(\mathrm{n}=9)$ \\
\hline Survival & $170(65 / 2024)$ & $190(30 / 2024)$ & $330(22 / 1392)$ \\
Nonsurvival & $240(20 / 2024)$ & $440(60 / 2024)$ & $1372(200 / 2024)^{2}$
\end{tabular}

${ }^{1}$ All values are median $\left(5^{\text {th }} / 95^{\text {th }}\right.$ percentiles $)$

${ }^{2} P=0.01$, Chi-square 9.21

tiles: 28/2024), whereas in nonsurviving patients 450 $\mathrm{pg} / \mathrm{mL}\left(5^{\text {th }} / 95^{\text {th }}\right.$ percentiles: 60/2024), with $P<0.01$ (Mann-Whitney U test).

We also tested the association of IL-6 promoter polymorphisms (-174 G/C) with IL-6 median concentration in survivors and nonsurvivors (Table 3 ). There was no association of genotype with median IL-6 plasma level in surviving severe sepsis patients $(P>0.05$, Kruskal-Wallis test), but in nonsurvivors we found significant differences between groups stratified by genotypes $(P=0.01$, Kruskal-Wallis test). A significantly increased median IL-6 plasma level was observed in nonsurviving patients with GG genotype$1372 \mathrm{pg} / \mathrm{mL}\left(5^{\text {th }} / 95^{\text {th }}\right.$ percentiles: 200/2024), compared with $\mathrm{C} / \mathrm{C}(240 \mathrm{pg} / \mathrm{mL}, 20 / 2024)$ and $\mathrm{C} / \mathrm{G}(440 \mathrm{pg} / \mathrm{mL}$, $60 / 2024)$.

\section{DISCUSSION}

In our study we found no significantly different distribution of IL-6 promoter genotypes between surviving and nonsurviving severe sepsis patients. Thus, we were not able to confirm the previously reported associations between IL-6 (-174 G/C) polymorphism and outcome in severe sepsis patients (Schlüter et al., 2002; Tischendorf et al., 2007). A possible explanation for this is that other factors (e.g. pre- 
existing disease, initial insult, therapeutic intervention etc.) influence the outcome.

We did find a significant difference in IL-6 plasma level between survivors and nonsurvivors, as reported previously (Schlüter et al., 2002).

We found an association between genotype and the IL-6 level in nonsurviving patients, but not in surviving patients. In nonsurvivors a significantly increased IL-6 plasma level was found in patients with the $\mathrm{G} / \mathrm{G}$ genotype. The observed association of G/G genotype with IL-6 level in the nonsurviving subgroup suggests a possible function of the $G / G$ genotype under specific clinical conditions (e.g., high level of IL-6 gene stimulation). Our observations confirm the previously reported association of $\mathrm{G}$ allele and increased IL-6 expression in healthy volunteers (Bennermo et al., 2004). Both in surviving and nonsurviving groups we observed the highest IL-6 level in the GG genotype, followed by the CG genotype and lowest in patients with the $\mathrm{C} / \mathrm{C}$ genotype. A similar distribution of IL-6 levels was previously reported (Tischendorf et al., 2007).

\section{ACKNOWLEGEMENTS}

This work was supported by grant 08.2200 of the Latvian Council of Science.

\section{REFERENCES}

Angus, D.C., Linde-Zwirble, W.T., Lidicker, J., Clermont, G., Carcillo, J., Pinsky, M.R. (2001). Epidemiology of severe sepsis in the United States: Analysis of incidence, outcome, and associated costs of care. Crit. Care Med., 29(7), 1303-1310.

Balding, J., Livingstone, W.J., Pittock, S.J., Mynett-Johnson, L., Ahern, T., Hodgson, A., Smith, O.P. (2004). The IL-6 G-174C polymorphism may be associated with ischaemic stroke in patients without a history of hypertension patients without a history of hypertension. Ir. J. Med. Sci., 173, 200-203.

Bennermo, M., Held, C., Stemme, S., Ericsson, C.-G., Silveira, A., Green, F., Tornvall, P. (2004). Genetic predisposition of the interleukin-6 response to inflammation: Implications for a variety of major diseases? Clin. Chem., 50(11), 2136-2140.

Borden, E.C., Chin, P. (1994). Interleukin-6: A cytokine with potential diagnostic and therapeutic roles. J. Lab. Clin. Med., 123, 824-829.

Casey, L.C., Balk, R.A., Bone, R.C. (1993). Plasma cytokine and endotoxin levels correlate with survival in patient with the septic syndrome. Ann. Intern. Med., 119, 771-778.

Fishman, D., Faulds, G., Jeffery, R., Mohamed-Ali, V., Yudkin, J.S., Humphries, S., Woo, P. (1998). The effect of novel polymorphisms in the interleukin- 6 (IL-6) gene on IL-6 transcription and plasma IL-6 levels, and an association with systemicv onset juvenile chronic arthritis. J. Clin. Invest., No. 102, 1369-1376.

Flex, A., Gaetani, E., Pola, R., Santoliquido, A., Aloi, F., Papaleo, P. (2002). The $174 \mathrm{G} / \mathrm{C}$ polymorphism of the interleukin- 6 gene promoter is associated with peripheral artery occlusive disease. Eur. J. Vasc. Endovasc. Surg., 24, 264-268.

Levy, M.M., Fink, M.P., Marshall, J.C., Abraham, E., Angus, D., Cook, D., Cohen, J., Opal, S.M., Vincent, J.-L., Ramsay, G. (2003). 2001 SCCM/ ESICM/ACCP/ATS/SIS international sepsis definitionsconference. Crit. Care Med., 31(4), 1250-1256.

Schlüter, B., König, B., Bergmann, U., Müller, F.E., König, W. (1991). Interleukin 6-a potential mediator of lethal sepsis after major thermal trauma: Evidence for increased IL-6 production by peripheral blood mononuclear cells. J. Trauma, No. 31, 1663-1670.

Schlüter, B., Raufhake, C., Erren, M., Schotte, H., Kipp, F., Rust, S., Van Aken, H., Assmann, G., Berendes, E. (2002). Effect of the interleukin-6 promoter polymorphism $(-174 \mathrm{G} / \mathrm{C})$ on the incidence and outcome of sepsis. Crit. Care Med., 32-37.

Tischendorf, J.J.W. et al. (2007) The interleukin-6 (IL6)-174 G/C promoter genotype is associated with the presence of septic shock and the ex vivo secretion of IL6. Int. J. Immunogen., 34(6) 413-418.

\section{INTERLEIKĪNA 6 (IL-6) GĒNA (-174 G/C) PROMOTERA POLIMORFISMA ASOCIĀCIJA AR IL-6 LİMENI UN KLĪNISKO IZNĀKUMU SMAGAS SEPSES SLIMNIEKIEM}

Interleikīns 6 (IL-6) ir nozīmīgs citokīns smagas sepses patoǵenēzē. IL-6 gēna promotera polimorfisma klīniskā nozīme smagas sepses slimniekiem arvien paliek neskaidra. Pētījuma mērķis ir noskaidrot IL-6 gēna promotera (-174 G/C) polimorfisma ietekmi uz IL-6 sistēmisko līmeni un klīnisko iznākumu smagas sepses slimniekiem. Pētījumā tika iekḷauti 103 Paula Stradinna Klīniskās universitātes slimnīcas Intensīvās terapijas un reanimācijas nodaḷas slimnieki ar apstiprinātu smagas sepses diagnozi. Pētījuma rezultātā nav konstatētas genotipu sadalījuma atšķirības izdzīvojušiem un mirušajiem smagas sepses slimniekiem. Novērota augstāka IL-6 plazmas koncentrācija mirušo slimnieku apakšgrupā. Genotipu saistība ar IL-6 plazmas līmeni konstatēta mirušo slimnieku apakšgrupā. Pētījuma rezultāti liecina par IL-6 (-174 G/C) polimorfisma funkcionālo nozīmīgumu neizdzīvojušiem smagas sepses slimniekiem. 